\title{
Structurally similar estradiol analogs uniquely alter the regulation of intracellular signaling pathways
}

\author{
James G Yarger, Robert E Babine', Michael Bittner², Erin Shanle ${ }^{3}$, Wei Xü ${ }^{3}$, \\ Pamela Hershberger ${ }^{4}$ and Steven H Nye \\ ENDECE, LLC, 1001 West Glen Oaks Lane, Suite 105B, Mequon, Wisconsin 53092, USA \\ ${ }^{1}$ Rebexsess Discovery Chemistry, Encinitas, California, USA \\ ${ }^{2}$ Translational Genomics Research Institute, Phoenix, Arizona, USA \\ ${ }^{3}$ McArdle Laboratory for Cancer Research, University of Wisconsin, Madison, Wisconsin, USA \\ ${ }^{4}$ Roswell Park Cancer Institute, Buffalo, New York, USA
}

Correspondence

should be addressed to

J G Yarger

Email

james.yarger@endece.com

\begin{abstract}
Ligand structure can affect the activation of nuclear receptors, such as estrogen receptors (ERs), and their control of signaling pathways for cellular responses including death and differentiation. We hypothesized that distinct biological functions of similar estradiol $\left(E_{2}\right)$ analogs could be identified by integrating gene expression patterns obtained from human tumor cell lines with receptor binding and functional data for the purpose of developing compounds for treatment of a variety of diseases. We compared the estrogen receptor subtype selectivity and impact on signaling pathways for three distinct, but structurally similar, analogs of $E_{2}$. Modifications in the core structure of $E_{2}$ led to pronounced changes in subtype selectivity for estrogen receptors, ER- $\alpha$ or ER- $\beta$, along with varying degrees of ER dimerization and activation. While all three $E_{2}$ analogs are predominantly ER- $\beta$ agonists, the cell growth inhibitory activity commonly associated with this class of compounds was detected for only two of the analogs and might be explained by a ligand-specific pattern of gene transcription. Microarray studies using three different human tumor cell lines demonstrated that the analogs distinctly affect the transcription of genes in signaling pathways for chromosome replication, cell death, and oligodendrocyte progenitor cell differentiation. That the $E_{2}$ analogs could lower tumor cell viability and stimulate neuronal differentiation confirmed that gene expression data could accurately distinguish biological activity of the $E_{2}$ analogs. The findings reported here confirm that cellular responses can be regulated by making key structural alterations to the core structure of endogenous ER ligands.
\end{abstract}
Key Words
- estradiol analogs
- estrogen receptors
- nuclear receptors
- DNA microarray
- multiple sclerosis
- cancer

\section{Introduction}

Nuclear receptors are transcription factors that play a key role in both embryonic development (Chung \& Cooney 2003) and adult homeostasis (Strauss et al. 2009, Colasanti et al. 2011, Ribas et al. 2011), and are a common target for drug developers treating human diseases such as cardiovascular, cancer, and autoimmune disorders (Deroo \& Korach 2006). Drugs in the market that modulate the activity of nuclear receptors represent over $\$ 30$ billion in pharmaceutical sales (Moore et al. 2006, Via 2010). Such drugs include prednisolone and

Published by Bioscientifica Ltd.

This is an Open Access article distributed under the terms of the Society for

Endocrinology's Re-use Licence which permits unrestricted non-commercial use ${ }_{2} 3$ 01:29:14PM distribution, and reproduction in any medium, provided the original work is properly. cited. 
dexamethasone for modulating glucocorticoid receptors (GRs), diethylstilbestrol and 4-hydroxytamoxifen for modulating estrogen receptors (ERs), and spironolactone (Aldactone) and eplerenone (Inspra) for modulating mineralocorticoid receptors (Moore et al. 2006). Interestingly, drugs that modulate the control of the same nuclear receptors are used to treat a diverse set of diseases, an effect that is attributed to the role of nuclear receptors in regulating many distinct intracellular pathways at the gene transcription level (Moore et al. 2006).

ERs are members of the nuclear receptor steroid family and have long been targets for therapeutic development, including the selective ER modulators (SERMs). The most prominent and best understood forms of the estrogen receptor are ER- $\alpha$ and ER- $\beta$, which share significant sequence homology (Barkhem et al. 1998), but display tissue-specific gene expression patterns (Couse et al. 1997), which can determine their use as effective therapeutic targets. In the case where ER- $\alpha$ and ER- $\beta$ are coexpressed in the same tissues, they can form active homo- or heterodimers upon binding ER ligands (Deroo \& Korach 2006). While several ER isoforms, such as ER- $\beta 2$, ER- $\beta 3$, ER- $\beta 4$, and ER- $\beta 5$ are known to exist, the biological significance of isoforms remains to be determined, although they may dimerize with ERs and enhance ER transactivation in a ligand-dependent manner (Paulmurugan et al. 2011). Estrogens and SERMs are known to bind and activate both ER- $\alpha$ and ER- $\beta$, making them useful for treating diseases, such as breast cancer, osteoporosis, and menopausal symptoms (Moore et al. 2006).

Binding of structurally dissimilar ER ligands can affect ER conformation along with the composition of the ER transcription complexes (Brzozowski et al. 1997). These phenomena may depend on the size and shape of the ligand-binding domains (LBDs), which vary between subtypes. The LBD for ER- $\alpha$ is substantially larger than for ER- $\beta, 450$ vs $390 \AA^{3}$ respectively (Ruff et al. 2000). This difference likely impacts the ER ligand-binding affinity, orientation of the ER ligand in the ligand-binding pocket, conformation of the ligand-bound ER, ER dimerization, coactivator and corepressor binding, and function of the receptors in their transcription complexes (Ruff et al. 2000). Helix 12 of both ER- $\alpha$ and ER- $\beta$ has been shown to be essential for transactivation of gene expression, as loss of function mutations within this region results in a nonfunctional receptor even in the presence of ligand (Danielian et al. 1992). Notably, the position of helix 12 in the ERs is thought to be dependent on the particular bound ER ligand, and the helix 12 position affects the receptor function. For example, when $17 \beta$-estradiol $\left(\mathrm{E}_{2}\right)$ is bound within the ligand-binding pocket of ER- $\alpha$, helix 12 is oriented over the ligand-binding cavity and is packed against helixes 3,5/6, and 11 in an agonist conformation (Brzozowski et al. 1997). By contrast, the binding of raloxifene within the ligand-binding pocket orients helix 12 to lie in a groove formed by helix 5 and the carboxy-terminal end of helix 3 in an antagonist conformation (Brzozowski et al. 1997).

Binding of different ligands to nuclear receptors, such as the ERs, can alter their conformation (Brzozowski et al. 1997, Shiau et al. 1998, Connor et al. 2001, Moore et al. 2006) resulting in ligand-dependent gene transcription profiles (Frasor et al. 2004, Paruthiyil et al. 2009). Studies with ER ligands have confirmed that slight changes in stereochemistry or modifications to small substituents can alter subtype selectivity and shift receptor-binding potency by orders of magnitude (Katzenellenbogen 2011). Accordingly, a plethora of ER ligands have been synthesized that are built around a diversity of core structures including polycyclic cores, acyclic cores, macrocyclic cores, and heterocyclic cores (Katzenellenbogen 2011). However, analogs designed for specificity to a particular ER subtype have not always aligned with the desired biological activity.

In this study, we used gene expression data obtained from three different human tumor cell lines as a predictor of biological function for closely related $\mathrm{E}_{2}$ analogs that were designed in-house. We employed ER-binding and functional assays to further examine the attributes of each ligand, along with cell-based assays to confirm the effect that specific ligand structures impart on the fate of cells. Beginning with the core $\mathrm{E}_{2}$ structure, analogs were devised with new substituents at the C- 6 of ring B or the C-18 of ring $D$. For the three $E_{2}$ analogs studied here, we show that subtle structural changes in the core $\mathrm{E}_{2}$ can affect both ER selectivity and gene expression pathways responsible for cell growth and differentiation. The potential of the three $\mathrm{E}_{2}$ analogs studied here for treating human diseases, such as multiple sclerosis and cancer, supports the viability of this approach for drug discovery.

\section{Materials and methods}

\section{Chemical synthesis}

Details for synthesis of the $E_{2}$ analogs (Fig. 1) are found in Supplementary Figure 1A, B and C, see section on supplementary data given at the end of this article. Briefly, NDC-1022 was prepared starting from $\mathrm{E}_{2}$ (Supplementary Figure 1A) and was obtained as a white solid with a purity of $98 \%$. As the starting material was $\mathrm{E}_{2}$, care was taken in

Published by Bioscientifica Ltd. 


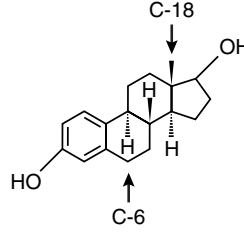

$\mathrm{E}_{2}$

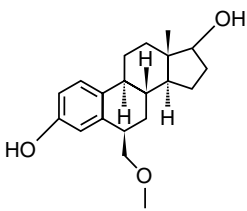

NDC-1022

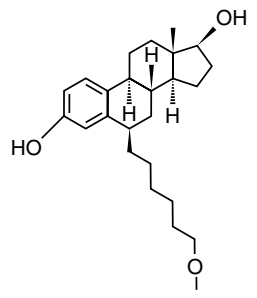

NDC-1308

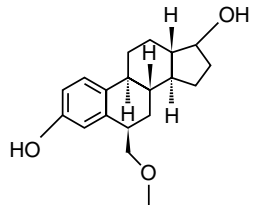

NDC-1352

\section{Figure 1}

Structures of the $E_{2}$ analogs. The analogs differ from $E_{2}$ and each other in either the length of the 6-alkoxyalkyl group at C-6 in the B ring or in the

column chromatography to ensure that $<10 \mathrm{ppm}_{2}$ was present in the final material used in the assays for these studies. The chiral purity of the $17 \beta$-isomer was at least $95 \%$. The compound was kept stored at under $-18^{\circ} \mathrm{C}$. NDC-1308 was prepared according to the scheme in Supplementary Figure 1B. Starting from E2, NDC-1308 was obtained as a solid, white foam with a purity of $95 \%$ and a chiral purity of $96 \%$. Since the starting material was $E_{2}$, care was taken in column chromatography to ensure that $<10$ ppm $\mathrm{E}_{2}$ was present in the final material. The compound was kept stored at under $-18^{\circ} \mathrm{C}$. NDC-1352 was prepared starting from NDC-1022 according to the scheme in Supplementary Figure 1C. NDC-1352 was obtained as a white solid with a purity of 95\% starting with NDC-1022. The compound was kept stored at under $-18{ }^{\circ} \mathrm{C}$.

For the biological assays, $\mathrm{E}_{2}$ and the $\mathrm{E}_{2}$ analogs were first dissolved in DMSO to a stock concentration of $10-100 \mathrm{mM}$ and then serially diluted to the appropriate concentrations.

\section{Cell lines}

Cell lines used for the cytotoxicity assay include NIHH23, CAPAN-1, CAPAN-2, MDA-MB-231, MCF-7, and OVCAR-3 obtained from ATCC (Manassas, VA, USA) or SK-OV-3, A-549 obtained from the NCBI (Bethesda, MD, USA). Cell lines were grown in RPMI (SK-OV-3, NCI-H23, MDA-MB231, A-549, MCF-7), RPMI with $10 \mathrm{mM}$ HEPES/20\%FBS (OVCAR-3), Iscove's Modified Dulbecco's Media (CAPAN-2), or McCoy's 5a Modified Media (CAPAN-1).

\section{Molecular modeling}

Modeling studies were performed with ICM-Pro v.3.6-1e licensed from Molsoft, LLC (San Diego, CA, USA).
() 2013 Society for Endocrinology Printed in Great Britain presence or absence of the C-18 methyl group in the D ring. The C- 6 in the $B$ ring and the $C-18$ in the $D$ ring of $E_{2}$ are denoted by arrows.

The coordinates for ER- $\alpha$ and ER- $\beta$ in various conformations were obtained from the Protein Data Bank (PDB, www.rcsb.org). The evaluation of several different coordinate files allowed us to explore protein flexibility. Generation of protein-ligand complexes, using different receptor conformations, was achieved using the Docking module in ICM-Pro. Evaluation of fitness of docks, and effects of the C-18 methyl group, was done by first generating docked complexes between the ligand of interest and ER- $\alpha$ (derived from PDB entry 1KQT) and ER- $\beta$ (derived from PDB entry 2J7X). These docks were then energy minimized to convergence using the Molecular Mechanics function using the 'boundary element' with a dielectric constant $=8$ for the electrostatic term. In this minimization, the ligand and protein residues within $5 \AA$ of the ligand were free to move while the rest of the protein was fixed. The energetics between the protein and the ligand of the minimized complex was then evaluated using the 'show energy' function using the 'vw, sf, el and en' terms.

\section{ER-binding assays}

Recombinant ER- $\alpha$ and ER- $\beta$ were supplied by PanVera (Madison, WI, USA). The ${ }^{3} \mathrm{H}-\mathrm{E}_{2}$ was obtained from New England Nuclear (Boston, MA, USA). The binding assay was carried out by incubating the recombinant ER- $\alpha$ or ER- $\beta$ with appropriate amount of ${ }^{3} \mathrm{H}-\mathrm{E}_{2}$ in the presence or absence of various concentrations of test compounds at $4{ }^{\circ} \mathrm{C}$ overnight in $200 \mu \mathrm{l}$ binding buffer with pH 7.4 (10 mM Tris-HCl, 10\% glycerol, 1\% albumin, $1 \mathrm{mM}$ phenylmethylsulfonyl fluoride, $25 \mathrm{nM}$ leupeptin). Various concentrations of nonlabeled $\mathrm{E}_{2}$ were tested in the same assay. Nonspecific binding was determined using a concentration of the nonradiolabeled $\mathrm{E}_{2}$ at 100 times that of the ${ }^{3} \mathrm{H}-\mathrm{E}_{2}$ in the same assay tube. At the

Published by Bioscientifica Ltd. 
end of incubation, the bound ${ }^{3} \mathrm{H}-\mathrm{E}_{2}$ was separated from the free unbounded ${ }^{3} \mathrm{H}-\mathrm{E}_{2}$ using $60 \%$ hydroxyapatite (HAP) in binding buffer. An aliquot of the supernatant was mixed with $4 \mathrm{ml}$ ScintiSafe (Fisher Scientific, Hampton, NH, USA) and the radioactivity was measured on a scintillation counter. The relative binding affinity of the test article was the amount of nonradioactive $\mathrm{E}_{2}$ required to displace $50 \%$ of radioactive $\mathrm{E}_{2}$ bound to $\mathrm{ER}$ relative to the amount of nonradioactive test compound required to displace $50 \%$ of radioactive $\mathrm{E}_{2}$ bound to $\mathrm{ER} \times 100$.

\section{Receptor dimerization assays}

Bioluminescent resonance energy transfer (BRET) assays were performed as previously described (Powell \& $\mathrm{Xu}$ 2008). Briefly, HEK293 cells were transfected with pCMX-ER $\alpha$-RLuc or pCMX-RLuc-ER $\beta$ BRET fusion constructs in combination with empty vector, pCMX-ER $\alpha$-YFP and pCMX-YFP-ER $\beta$. The following cotransfections were used to assess dimer formation: pCMX-ER $\alpha$-RLuc/pCMX-ER $\alpha$-YFP for ER- $\alpha$ homodimers, pCMX-ER $\alpha$-RLuc/pCMX-YFP-ER $\beta$ for heterodimers, and pCMX-RLuc-ER $\beta /$ pCMX-YFP-ER $\beta$ for ER- $\beta$ homodimers. Twenty-four hours after transfection, $\sim 50000$ cells/well suspended in PBS were seeded in triplicate onto a white 96-well plate and treated with the corresponding compounds or vehicle (0.6\% DMSO). After an $1 \mathrm{~h}$ incubation with ligand, coelenterazine $\mathrm{h}$ (Promega) was added to a final concentration of $5 \mu \mathrm{M}$, and emission at 460 and $530 \mathrm{~nm}$ was detected using a Victor X5 microplate reader. BRET ratios were calculated as described previously (Powell \& Xu 2008), and the ratios represent the energy transfer between the donor and acceptor molecules. Higher BRET ratios are indicative of dimerization.

\section{Gene transcription assays}

The plasmids for ER-binding element luciferase reporter (pERE) and for ER- $\beta$ cDNA expression vector (pER- $\beta$ ) were supplied by Addgene (Cambridge, MA, USA). The plasmid for the ER- $\alpha$ cDNA expression vector (pER- $\alpha$ ) was obtained from OriGene Technologies, Inc. (Rockville, MD, USA). The Dual-Luciferase kit for measuring luminescence was obtained from Promega. MDA-MB-231 cells were seeded in 12-well plates at a density of $1.5 \times 10^{5}$ cells/well in medium without antibiotics. Cells were allowed to grow overnight to $50-70 \%$ confluence before transfection. For transfection, an appropriate amount of pERE, pER- $\alpha$ or pER- $\beta$ reporter plasmid and internal control plasmid pRLTK was cotransfected transiently into cells. Transfection was performed using TurboFectin8 (OriGene) according to the protocol provided by the supplier. Cells were then treated with either $E_{2}$ or the $E_{2}$ analogs. After incubating for $24 \mathrm{~h}$ at $37^{\circ} \mathrm{C}$, cells were washed once with PBS, and then lysed with buffer provided by the supplier. The ratio of firefly compared with renilla luminescence was calculated for each treatment group. The functional expression of each compound was expressed as a percentage of the $\mathrm{E}_{2}$ ratio (100\%) measured at $10 \mathrm{nM}$.

\section{DNA microarray}

Three human tumor cell lines, A-549, Panc-1, and SK-OV-3, were selected based on their endogenous levels of ER- $\alpha$ and ER- $\beta$ and each grown in two flasks cultured to roughly $50 \%$ confluence. Cells were treated for $24 \mathrm{~h}$ with either the $\mathrm{E}_{2}$ analogs or $10 \%$ DMSO at concentrations of compound specified in Table 1. At termination, the cells were scraped free and washed in ice-cold PBS, collected by centrifugation, and immediately frozen at $-80^{\circ} \mathrm{C}$. Total RNA was prepared from the frozen tissue samples using Trizol-based cell lysis followed by $65^{\circ} \mathrm{C}$ hot phenol extraction and RNeasy chromatography purification (Qiagen). The concentration of RNA was determined by measuring the absorbance at $260 \mathrm{~nm}$ (A260). RNA purity was assessed by confirming that extracted RNAs had an A260/A280 ratio of 1.8 or greater. The RNA was then tested for relative integrity by determining the ratio of intact $28 \mathrm{~S}$ and $18 \mathrm{~S}$ rRNAs by capillary electrophoresis with the Agilent 2100 BioAnalyzer (Agilent Technologies, Santa Clara, CA, USA). All RNAs accepted for array analysis had ratios exceeding 1.0.

RNAs were labeled using $1 \mu \mathrm{g}$ RNA as input to Low Input labeling reaction (Agilent Technologies) with Cy5 (650 nm emitter) and reference RNA was labeled with Cy3 (550 nm emitter) nucleotides. Labeling, hybridizations, and subsequent washings were carried out on with the Human GE 4x44K v2 G4110B (NDC-1308, NDC-1022) or the Human GE 4x44K v2 G4845A (NDC-1352) microarray kits from Agilent Technologies, according to the manufacturer's instructions. The resulting hybridized chips were scanned (G2505 Scanner, Agilent Technologies), and the intensity information for each detector spot was extracted from the scanned image using Agilent feature extraction software version 10.5.1.1. The filtered raw data for each microarray spot can be accessed in Supplementary Table 1, see section on supplementary data given at the end of this article. For analysis, a threshold of $P \leq 0.001$ was used as the cutoff point for significant change in mRNA abundance between the compound-treated and vehicle-treated samples.

Published by Bioscientifica Ltd. 
Table 1 Distinct gene expression patterns in human tumor cell lines induced by the $E_{2}$ analogs

\begin{tabular}{|c|c|c|c|c|c|c|c|c|}
\hline \multirow[b]{3}{*}{ Gene name } & \multirow[b]{3}{*}{ Symbol } & \multirow{3}{*}{$\begin{array}{l}\text { Entrez } \\
\text { gene } \\
\text { GeneID }\end{array}$} & \multicolumn{6}{|c|}{ Gene expression values ${ }^{a, b}$} \\
\hline & & & \multicolumn{2}{|c|}{ NDC-1022 } & \multicolumn{2}{|c|}{ NDC-1308 } & \multicolumn{2}{|c|}{ NDC-1352 } \\
\hline & & & $50 \mu \mathrm{M}$ & $100 \mu \mathrm{M}$ & $10 \mu \mathrm{M}^{\mathrm{d}}$ & $50 \mu \mathrm{M}$ & $25 \mu \mathrm{M}$ & $100 \mu \mathrm{M}$ \\
\hline \multicolumn{9}{|l|}{ Oligodendrocyte progenitor cell differentiation } \\
\hline Delta/notch-like EFG repeat containing & DNER & 92737 & 5.16 & 5.51 & 6.20 & 4.79 & 0.00 & 0.00 \\
\hline Oligodendrocyte lineage transcription factor 2 & OLIG2 & 10215 & 4.98 & 4.59 & 6.16 & 5.32 & 0.00 & 0.00 \\
\hline Myelin basic protein & MBP & 4155 & 4.72 & 4.80 & 6.07 & 5.04 & 0.00 & 0.00 \\
\hline Myelin oligodendrocyte glycoprotein & MOG & 4340 & 3.99 & 4.28 & 5.23 & 5.55 & 0.00 & 0.00 \\
\hline Interleukin 23 receptor & IL23R & 149233 & 3.62 & 4.86 & 5.31 & 5.46 & 0.00 & 0.00 \\
\hline Transmembrane protein 108 & TMEM108 & 66000 & 3.59 & 3.62 & 3.92 & 3.96 & 0.00 & 0.00 \\
\hline Connexin & AF251047 & 100128922 & 3.38 & 3.56 & 2.74 & 3.08 & 0.00 & 0.00 \\
\hline Interleukin 20 receptor alpha & IL20RA & 53832 & 3.17 & 3.38 & 4.42 & 4.39 & 0.00 & 0.00 \\
\hline Interferon, lambda 2 & IFNL2 & 282616 & 1.35 & 1.96 & 1.44 & 2.59 & -0.37 & -0.37 \\
\hline \multicolumn{9}{|l|}{ Chromosome replication } \\
\hline Cell division cycle 25 homolog B & CDC25B & 994 & 0.00 & 0.00 & 0.00 & -0.71 & 0.00 & 0.00 \\
\hline Minichromosome maintenance complex component 6 & MCM6 & 4175 & 0.00 & -0.43 & 0.00 & -1.76 & 0.00 & 0.00 \\
\hline Flap structure-specific endonuclease 1 & FEN1 & 2237 & 0.00 & -0.52 & -0.47 & -1.76 & 0.00 & 0.00 \\
\hline Minichromosome maintenance complex component 4 & MCM4 & 4173 & 0.00 & -0.58 & -0.29 & -2.08 & 0.00 & 0.00 \\
\hline Minichromosome maintenance complex component 10 & MCM10 & 55388 & 0.00 & -0.68 & -0.24 & -2.17 & 0.00 & 0.00 \\
\hline Origin recognition complex, subunit 1 & ORC1L & 4998 & 0.00 & -0.74 & -0.60 & -1.68 & 0.43 & 0.27 \\
\hline Aurora kinase $\mathrm{A}$ & AURKA & 6790 & 0.00 & -0.73 & -0.46 & -1.44 & 0.00 & 0.00 \\
\hline G-2 and S-phase expressed 1 & GTSE1 & 51512 & 0.00 & -0.82 & -0.53 & -2.33 & 0.26 & 0.18 \\
\hline Spindle pole body component 25 homolog & SPC25 & 57405 & 0.00 & -0.82 & -0.29 & -2.28 & 0.00 & 0.00 \\
\hline Minichromosome maintenance complex component 7 & MCM7 & 4176 & 0.00 & -0.83 & 0.00 & -0.99 & 0.00 & 0.00 \\
\hline GINS complex subunit 1 & GINS1 & 9837 & 0.00 & -0.93 & -0.47 & -1.94 & 0.00 & 0.00 \\
\hline PIF1 5'-to-3' DNA helicase homolog & PIF1 & 80119 & 0.00 & -1.19 & -0.50 & -1.70 & 0.00 & 0.00 \\
\hline Kinesin family member 20A & KIF20A & 10112 & -0.38 & -1.06 & -0.38 & -1.06 & 0.00 & 0.00 \\
\hline Cell division cycle associated 8 & CDCA8 & 55143 & -0.25 & -1.16 & -0.22 & -1.14 & 0.00 & 0.00 \\
\hline Replication factor C (activator 1) 3, $38 \mathrm{kDa}$ & RFC3 & 5983 & -0.78 & -0.97 & -0.57 & -1.84 & 0.40 & 0.34 \\
\hline \multicolumn{9}{|l|}{ Cell death } \\
\hline Growth differentiation factor 15 & GDF15 & 9518 & 1.26 & 2.50 & 1.36 & 3.47 & 0.49 & 0.81 \\
\hline Calreticulin 3 & CALR3 & 125972 & 0.59 & 2.07 & 1.99 & 1.99 & 0.00 & 0.00 \\
\hline Growth arrest and DNA-damage-inducible, alpha & GADD45A & 1647 & 0.00 & 0.00 & 0.32 & 4.60 & 0.00 & 0.00 \\
\hline Granzyme K & GzmK & 3003 & 0.00 & 0.00 & 3.94 & 3.73 & 0.00 & 0.00 \\
\hline Apoptosis enhancing nuclease & AEN & 64782 & 0.00 & 0.00 & 0.36 & 1.13 & 0.00 & 0.00 \\
\hline \multicolumn{9}{|l|}{ Immune system/inflammation } \\
\hline Chemokine ( $\mathrm{C}-\mathrm{C}$ motif) ligand 11 & CCL11 & 6356 & 0.00 & 0.00 & 0.00 & 0.00 & 8.66 & 8.39 \\
\hline Complement component 6 & $\mathrm{C} 6$ & 729 & 0.00 & 0.00 & 0.00 & 0.00 & 8.20 & 7.47 \\
\hline Chemokine (C-X-C motif) receptor 2 , pseudogene 1 & CXCR2P1 & 3580 & 0.00 & 0.00 & 0.00 & 0.00 & 7.80 & 8.06 \\
\hline ADAM metallopeptidase with thrombospondin type 1 motif, 8 & ADAMTS8 & 11095 & 0.00 & 0.00 & 0.00 & 0.00 & 4.42 & 4.03 \\
\hline ADAM metallopeptidase with thrombospondin type 1 motif, 14 & ADAMTS14 & 140766 & 0.00 & 0.00 & 0.00 & 0.00 & 4.20 & 3.88 \\
\hline Chemokine (C-C motif) ligand 22 & CCL22 & 6367 & 0.00 & 0.00 & 0.00 & 0.00 & 3.82 & 3.49 \\
\hline Chemokine (C-C motif) ligand 1 & CCL1 & 6346 & 0.00 & 0.00 & 0.00 & 0.00 & 1.66 & 3.20 \\
\hline Chemokine (C-C motif) ligand 8 & CCL8 & 6355 & 0.00 & 0.00 & 0.00 & 0.00 & 1.66 & 3.20 \\
\hline \multicolumn{9}{|l|}{ Housekeeping } \\
\hline Actin, alpha 2, smooth muscle, aorta & ACTA2 & 59 & 0.00 & 0.47 & 0.00 & 0.00 & 0.00 & -0.24 \\
\hline Ubiquitin B & UBB & 7314 & 0.00 & 0.00 & 0.00 & -0.48 & 0.00 & -0.24 \\
\hline Glyceraldehyde-3-phosphate dehydrogenase & GAPDH & 2597 & 0.00 & 0.00 & 0.00 & -0.20 & 0.00 & 0.00 \\
\hline Actin, beta & АСТВ & 60 & 0.00 & -0.29 & 0.00 & -0.88 & 0.00 & -0.59 \\
\hline Ubiquitin D & UBD & 10537 & 0.00 & -1.09 & -0.55 & -0.68 & 0.00 & 0.00 \\
\hline
\end{tabular}

${ }^{a} A$ Il values are Log 2 and represent the average of three independent microarray experiments.

${ }^{b}$ Significant changes in gene expression, $P<0.0001$.

'Gene IDs conform to standards developed at the NCBI for the Entrez Gene database.

${ }^{d}$ The $E_{2}$ analogs have different potencies for inhibiting cell growth; gene expression was tested at the lowest concentration for the more potent NDC-1308.

http://www.jme.endocrinology-journals.org @ 2013 Society for Endocrinology DOI: $10.1530 / J M E-12-0083$ 


\section{Cytotoxicity assays}

NDC-1022, NDC-1308, NDC-1352, $\mathrm{E}_{2}$ (Sigma), and tamoxifen (Sigma) were each dissolved in DMSO at $100 \mathrm{mM}$. For dilutions, the $100 \mathrm{mM}$ DMSO stock was added to the appropriate media and serially diluted in the same media such that the final DMSO contribution was $\leq 1 \%(\mathrm{v} / \mathrm{v})$.

Each cell line was maintained at $5 \% \mathrm{CO}_{2}, 37^{\circ} \mathrm{C}$, and $95 \%$ relative humidity in the appropriate media including all necessary supplements. The cells were subcultured every 2-3 days and plated in tissue culturetreated, white/clear-bottom 96-well plates and incubated at $5 \% \mathrm{CO}_{2}$ and $37^{\circ} \mathrm{C}$ overnight before initiation of the assay. The media in the cell plate $(100 \mu \mathrm{l})$ was replaced with fresh media $(100 \mu \mathrm{l})$ immediately before adding the $100 \mu$ l test articles; the media were not estrogen-depleted. Wells containing no cells were used for background controls. Tamoxifen was used as a known positive control for each assay and DMSO was included as the vehicle control. The cells were incubated at $\sim 37^{\circ} \mathrm{C}$ in humidified $5 \% \mathrm{CO}_{2}$ atmosphere for $72 \mathrm{~h}$.

Cell number was determined by measuring the ATP levels using the CellTiter-Glo Kit (Promega). Luminescence was measured with the Infinite M200 plate reader (Tecan, Durham, NC, USA). The mean baseline controls (wells with no cells) were subtracted from the total luminescence to determine the net luminescence for that well. This total was compared with the vehicle control of DMSO only. Both $\mathrm{EC}_{50}$ and $\mathrm{EC}_{90}$ values were calculated using Sigma Plot 11.0 (Systat Software, Inc., San Jose, CA, USA). The lower $\mathrm{EC}_{90 / 50}$ values help to identify cell lines that are more susceptible to compounds.

\section{Oligodendrocyte differentiation assays}

Oligodendrocyte precursor cell (OPC) cultures were prepared as previously described (Pedraza et al. 2008). Briefly, brains were removed from E14.5 C57B16/J (expressing PLP-EGFP) mice (Mallon et al. 2002), cleaned, and cortical hemispheres were isolated. Tissue was then triturated and seeded into $\mathrm{T}-25 \mathrm{~cm}^{2}$ flasks at a density of one brain (two cortical hemispheres) per flask. Neurospheres were passed once after 3 days. Cells from passage two were used to prepare two 96-well plates for the primary screen. Following the initial $48 \mathrm{~h}$ incubation in OPC media, the OPCs were treated with $10 \mu \mathrm{M}$ of $\mathrm{E}_{2}$, NDC-1022, NDC-1308, and NDC-1352 along with vehicle control DMSO and positive control compounds including $20 \mathrm{ng} / \mathrm{ml}$ ciliary neurotrophic factor (CNTF) and $1 \mu \mathrm{M}$ ERK kinase inhibitor (MEKi). Cells were treated for a total of 4 days and the media was replaced once at the $48 \mathrm{~h}$ mark with fresh compounds. After the 4 day treatment, the cells were fixed with $4 \%$ paraformaldehyde and stained with Hoechst 33342 to visualize nuclei. Cells were also stained with anti-GFAP antibodies to identify astrocytes. Briefly, cells were blocked with 3\% normal goat serum followed by an overnight incubation of anti-rabbit GFAP antibody (1:500). Cells were labeled with a 1:1000 concentration of secondary goat anti-rabbit Alexa 647 fluorochrome antibody. Images were acquired using the Cellomics Arrayscan VTI. Twenty fields at $10 \times$ magnification were acquired per well and the cells expressing EGFP (mature oligodendrocytes) and GFAP (astrocytes) were evaluated by neuronal profiling algorithm.

\section{Statistical analysis}

For the BRET assays, the values for each compound were compared with DMSO control for each dimer condition using a one-tailed Student's $t$-test with significant difference $P<0.05$. For the DNA microarray studies, significant $(P<0.001)$ up- or downregulated genes were identified by comparing the $\mathrm{E}_{2}$ analog-treated and vehicle-treated samples from each tumor cell line. Genes were included in the relevant signaling pathways (Table 1) only if they were consistently regulated in the same manner for all three tumor cell lines. For the oligodendrocyte differentiation studies, ANOVA showed statistically significant differences $(P<0.001)$ between the different treatment groups. Comparisons of $\mathrm{E}_{2}$ analogs, MEKi, and CNTF were then made to control DMSO using a Student's t-test with significant difference $P<0.001$.

\section{Results}

\section{Molecular modeling of $E_{2}$ analogs in the ER LBD}

The structures of $\mathrm{E}_{2}$ and the synthesized $\mathrm{E}_{2}$ analogs are shown in Fig. 1. Alkoxyalkyl substituents were added to the C- 6 position of the $\mathrm{E}_{2}$ B-ring for all three analogs while the C-18 methyl was removed to create NDC-1352 (Supplementary Figure 1A, B and C).

Docking studies of these compounds to various receptor conformations, allowing for the exploration of protein flexibility of both ER- $\alpha$ and ER- $\beta$, were carried out using the docking algorithm implemented in ICMpro and generated two possible docking poses. Using NDC-1022 as an example,

Published by Bioscientifica Ltd. 
in one pose (Fig. 2A and B) the steroid core would bind in the same manner that $\mathrm{E}_{2}$ does ( $\mathrm{E}_{2}$-like). In the second pose (Fig. 2C) the $\mathrm{E}_{2}$ analogs bind in an 'upside down' manner similar to the way both 16- $\alpha, \mathrm{E}_{2}$ (DOI: $10.2210 / \mathrm{pdb} 2 \mathrm{j} 7 \mathrm{y} / \mathrm{pdb}$ ) (Pike et al. 2001) and ICI 164384 (DOI: 10.2210/pdb1hj1/ pdb) bind. These two different binding modes represent isomeric complexes of a single compound, differing in both the relative position of the ligand in the binding site and the conformation of the protein. It should be noted that for ER- $\beta$, the binding affinity decreases with ligand volume, whereas for ER- $\alpha$, binding affinity increases with ligand volume, which is consistent with this model.

We propose the $\mathrm{E}_{2}$-like docking pose as the most likely pose for the $\mathrm{E}_{2}$ analogs studied here. In the $\mathrm{E}_{2}$-like orientation for NDC-1308 (Fig. 2D), the C-6 alkoxyalkyl groups of the $\mathrm{E}_{2}$ analogs could fold on top of the steroid core of the ligand, binding to a pocket of the ERs that $\mathrm{E}_{2}$ would not be able to interact. The C-6 groups in this orientation could fit into a small hydrophobic pocket formed by the side chain of Met-291, Leu-294, and

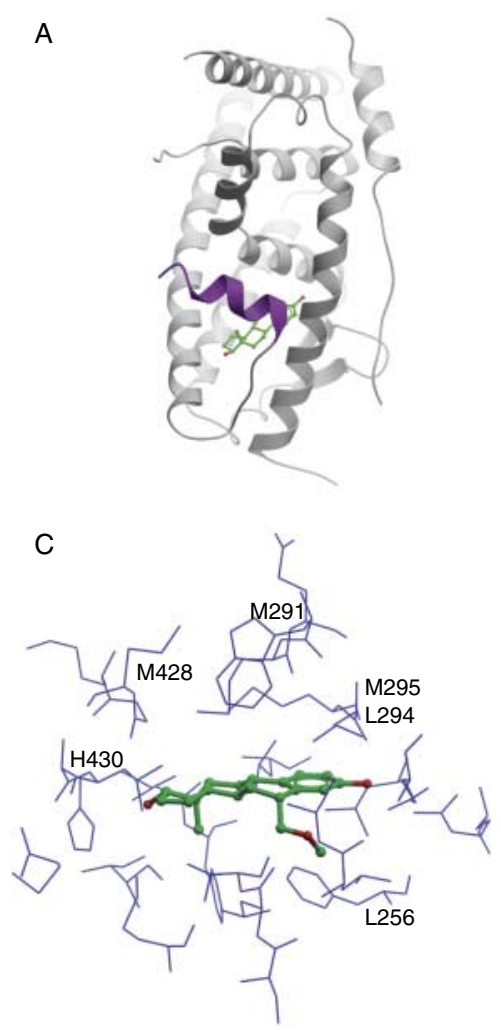

Figure 2

Docking analysis of $E_{2}$ analogs into the ER- $\alpha$ and ER- $\beta$ ligand-binding domains. (A) $E_{2}$-like docking pose of NDC-1022 (green) to the ER- $\beta$ agonist conformation (helix 12 purple). (B) There are subtle differences in the residues making contact with the ligand between ER- $\alpha$ (red residue labels)

(C) 2013 Society for Endocrinology Printed in Great Britain
Met-295 of ER- $\beta$ (corresponding to Leu-384, Leu-387, and Met-388 of ER- $\alpha$ ) although this appears to be a rather crowded fit. We predict that this crowded fit results in subtle conformational changes in the ER leading to altered transcriptional activities.

In the $\mathrm{E}_{2}$-like bound orientation of NDC-1022, the C-6 side chain could make van der Waals interactions with the C-18 methyl. In NDC-1352, the C-18 methyl is absent. To simplify the modeling analysis, the effect of the C-18 methyl was examined by comparing the binding of $\mathrm{E}_{2}$ with nor-C-18-methyl-E 2 (norMe_E $E_{2}$. For ER- $\beta$, norMe_E $E_{2}$ had slightly more favorable van der Waals interactions than did $E_{2}$. For ER- $\alpha$, the situation was reversed in that norMe_E $E_{2}$ had slightly less favorable van der Waals interactions than did $E_{2}$. It should be noted that for ER- $\alpha$, the C-18 methyl group of $\mathrm{E}_{2}$ makes van der Waals interactions with the side chain of Leu-384, whereas with norMe_E $E_{2}$ with a hydrogen at this position, a small gap between ligand and protein is created. For ER- $\beta$, the C-18 methyl group of $\mathrm{E}_{2}$ interacts with the side chain Met-291.

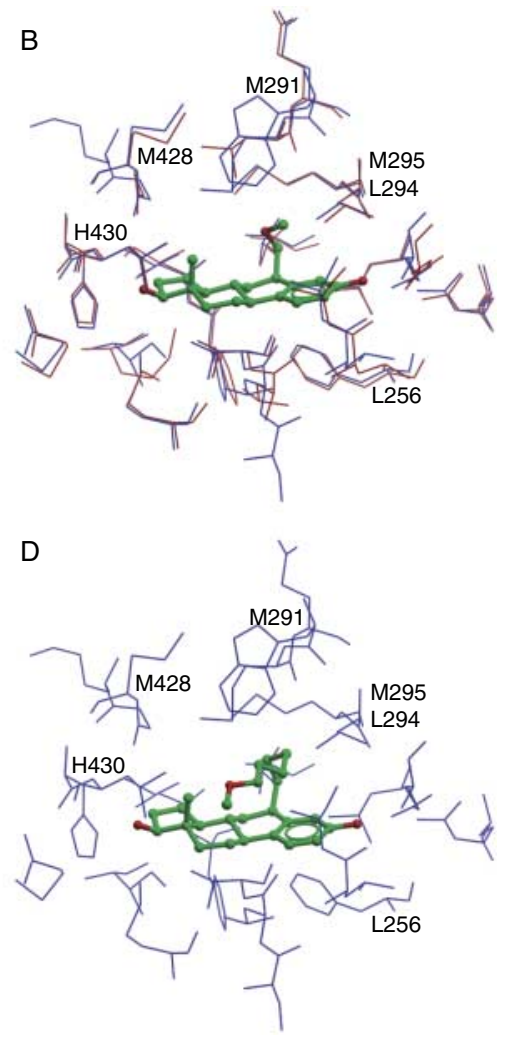

and ER- $\beta$ (blue residue labels). See text for details. (C) Alternate 'upside-down' docking pose of NDC-1022 (green). (D) Ligand NDC-1308 (green) bound to ER- $\beta$ (blue residue labels) in the $E_{2}$-like orientation. Figures were created with ICMpro v3.7-2c.

Published by Bioscientifica Ltd 
As the methionine side chain is somewhat flexible, it is better able to fill in the gap between the C-18 hydrogen in norMe_E $E_{2}$ and the ER- $\beta$ protein. Similarly, the somewhat flexible nature of Met-291 in ER- $\beta$ might allow for a better induced fit of the C-6 side chain of NDC-1352 within ER- $\beta$ compared with the less flexible Leu-384 of ER- $\alpha$. Thus, the substitution of the C-18 methyl group of NDC-1022 for a hydrogen in NDC-1352 is expected to result in an increased $\beta$-selectivity of NDC-1352. The $\mathrm{E}_{2}$ like binding pose represents the agonist conformation of the ER and provides a better proposed fit for the $\mathrm{E}_{2}$ analogs compared with the 'upside down' binding pose (Fig. 2C).

\section{Binding of the $E_{2}$ analogs to ERs}

Each $E_{2}$ analog along with reference $E_{2}$ was assessed for binding affinity to ER- $\alpha$ and ER- $\beta$ using in vitro recombinant receptor binding assays. The analogs were found to possess distinctly different binding affinities for ER- $\alpha$ and ER- $\beta$ (Table 2 ). Although it has a large alkoxyalkyl moiety at C- 6 , the $1 / \beta$ : $\alpha$ ratio for NDC-1308 shows that there is no significant preference for binding either ER- $\alpha$ ( $\left.\mathrm{IC}_{50} 70 \mathrm{nM}\right)$ or ER- $\beta$ ( $\left.\mathrm{IC}_{50} 100 \mathrm{nM}\right)$, similar to $\mathrm{E}_{2}$. On the other hand, NDC-1022 and NDC-1352 each have a smaller alkoxyalkyl moiety at C-6 and are structurally more similar to $\mathrm{E}_{2}$ than NDC-1308, yet both preferentially bind ER- $\beta$ over ER- $\alpha$. NDC-1022 had a greater than sixfold higher binding affinity to ER- $\beta$ than ER- $\alpha$, while NDC-1352 had a $>100$-fold higher affinity to ER- $\beta$. The different ER- $\beta /$ ER- $\alpha$ binding ratios for NDC-1022 compared with NDC-1352 demonstrate the impact that a seemingly innocuous hydrogen substitution (NDC-1352) for a methyl group (NDC-1022) at C-18 can make on receptor binding in combination with an alkoxyalkyl moiety at C-6.

While some ligands have been found to cross-react with different classes of hormone receptors (Kimbrel \& McDonnell 2003), there was no significant binding of either NDC-1308 or NDC-1022 to the androgen (AR), progesterone (PR), or GR receptors. The $\mathrm{IC}_{50 \text { s }}$ for DHT (AR control), progesterone (PR control), and dexamethasone (GR control) were $8.5,1.3$, and $6.6 \mathrm{nM}$ respectively. By contrast, the $\mathrm{IC}_{50}$ of NDC-1022 was $>3000 \mathrm{nM}$ for all three receptors, while the $\mathrm{IC}_{50}$ of NDC-1308 was $>3000 \mathrm{nM}$ for $\mathrm{AR}$ and $\mathrm{GR}$ and $1200 \mathrm{nM}$ for PR. NDC-1352 was not evaluated in this assay.

\section{Dimerization of ERs following $E_{2}$ analog binding}

The binding of exogenous ligands to ER- $\alpha$ and ER- $\beta$ and subsequent dimer formation is an initial step required for

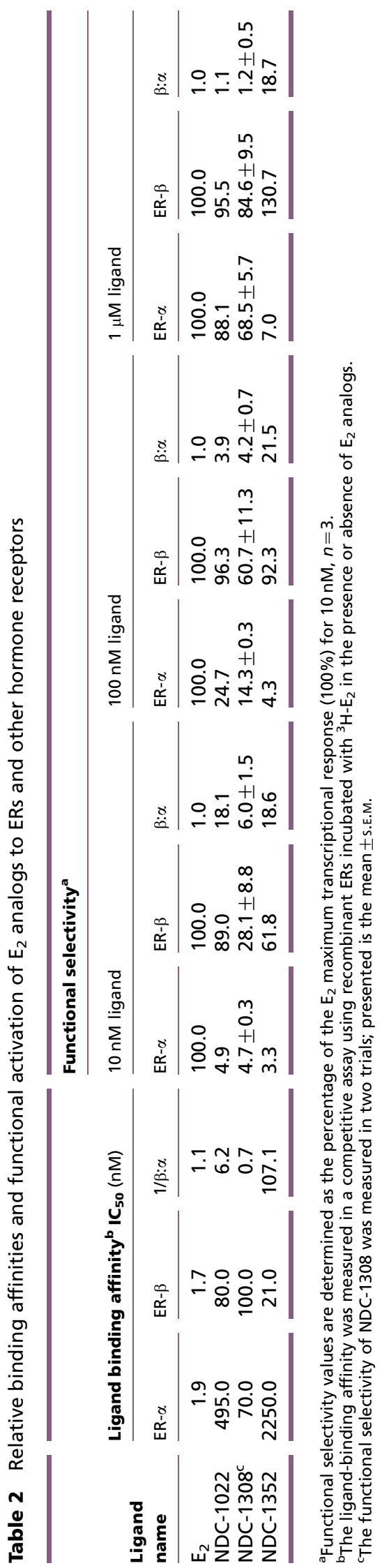

Published by Bioscientifica Ltd. 
transcriptional activation. In cells expressing both ER- $\alpha$ and ER- $\beta$, homo- and heterodimers can readily form following the binding of estrogens (Deroo \& Korach 2006). NDC-1022 and NDC-1308 were tested for their ability to cause homo- and heterodimer formation in vitro using a BRET assay that measures the ER $\alpha / \beta$ heterodimerization in a cell-based physiological environment in real time (Pfleger \& Eidne 2006, Powell \& Xu 2008). Although NDC-1022 caused all combinations of homo- and heterodimers to form at concentrations of $1 \mu \mathrm{M}$ or greater, $\alpha / \beta$ heterodimers and $\beta / \beta$ homodimers were preferred at $100 \mathrm{nM}$ (Fig. 3A). By contrast, NDC-1308 induces all dimer formations starting at $1 \mu \mathrm{M}$ but with no preference for either form (Fig. 3B). BRET assays for ER- $\beta$ homodimeriza- tion typically show 1.5- to 2-fold inductions with $\mathrm{E}_{2}$ treatment because of high ligand-independent dimerization, which has been previously described by Powell \& $\mathrm{Xu}$ (2008). In addition, conformational changes within the receptor fusion proteins allow for efficient energy transfer, and the BRET ratios are dependent on the conformational changes induced by different ligands, thereby affecting the BRET ratio output. Although NDC1022 and NDC-1308 do not induce BRET ratios to the same extent as $E_{2}$, there is significant ER dimerization induced by both compounds. Since ERs are transcription factors, the ability of these $\mathrm{E}_{2}$ analogs to form ER dimers in vitro suggested that they would drive gene expression in cells.
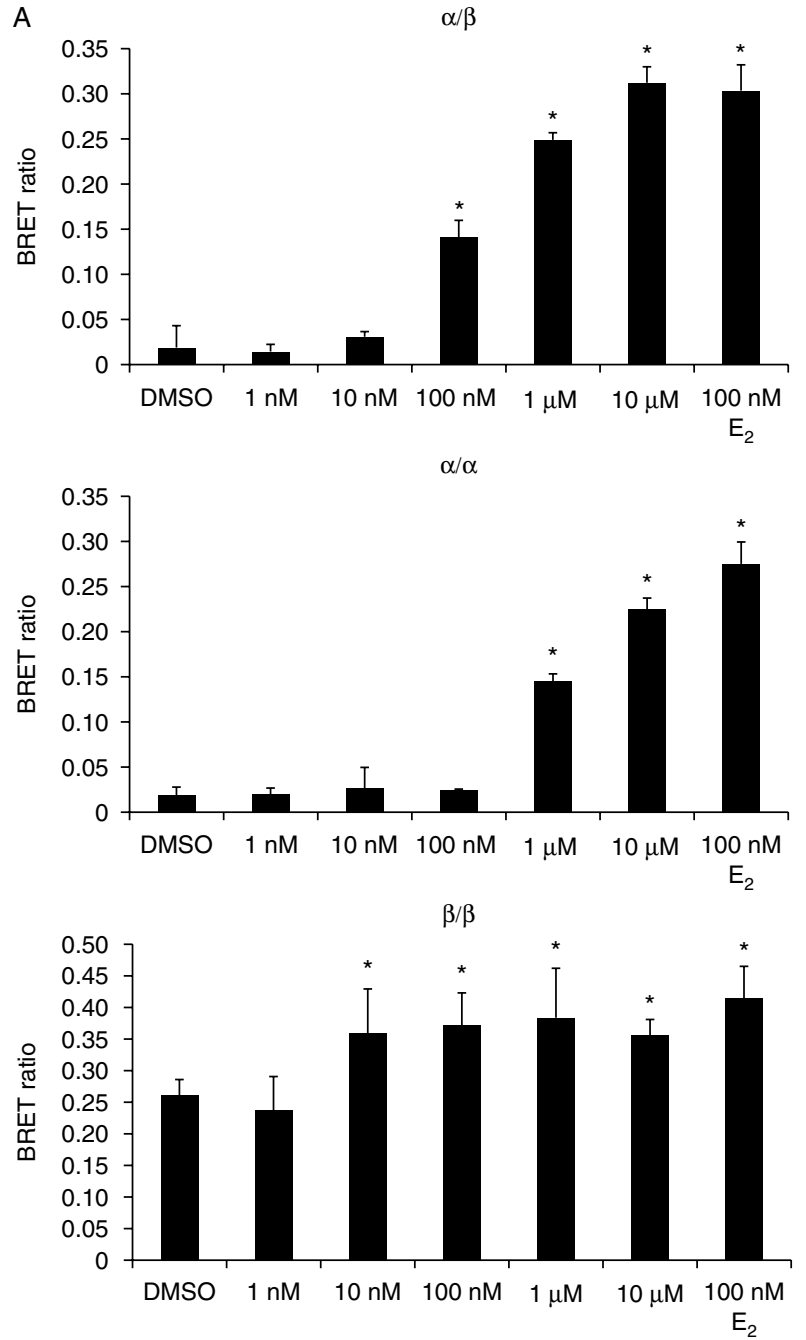

Figure 3

BRET assays for determining ER $\alpha / \beta$ dimer formation by the $E_{2}$ analogs. Shown is the level of $\alpha / \alpha, \alpha / \beta$, or $\beta / \beta$ dimer formation induced by (A) NDC-1022

(C) 2013 Society for Endocrinology Printed in Great Britain
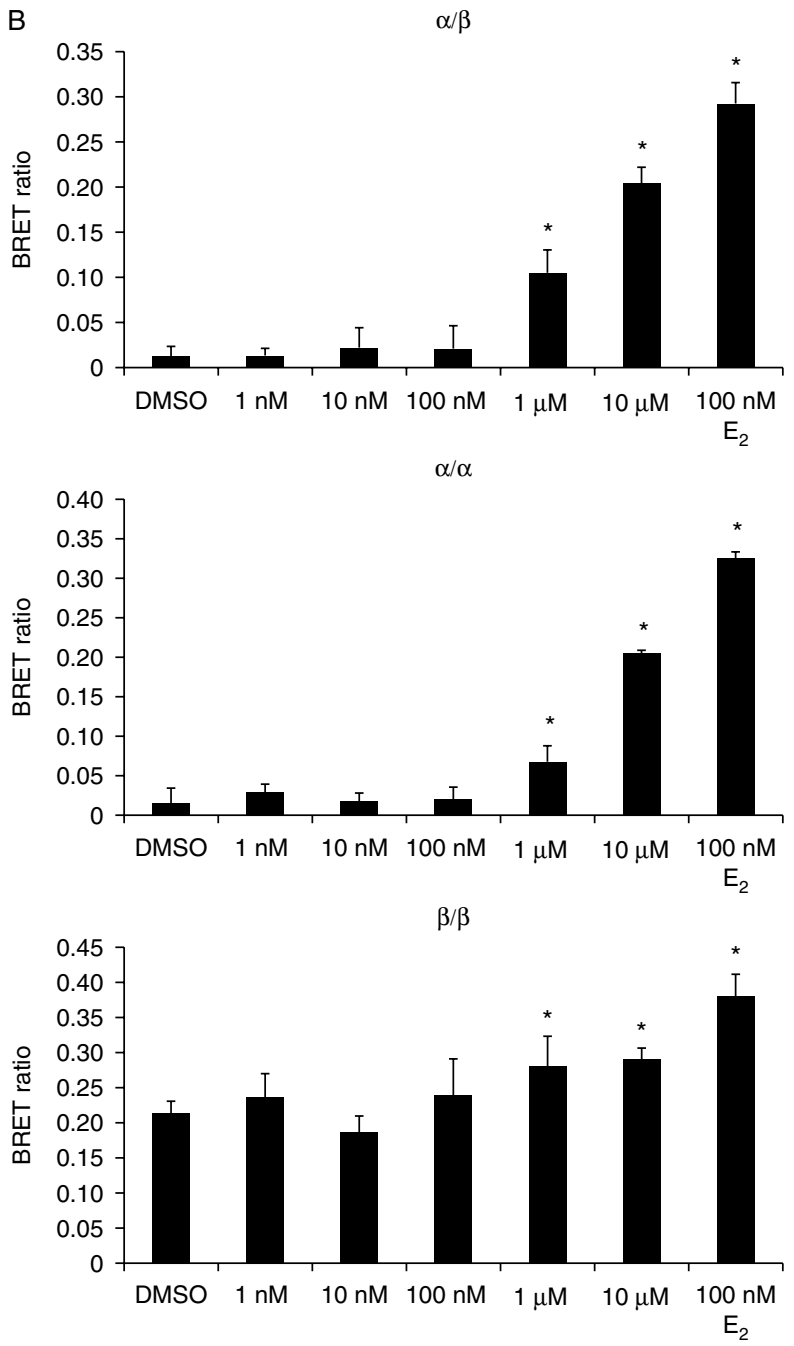

and (B) NDC-1308. Data are representative of three independent experiments. Mean values are plotted with s.D., $n=3 .{ }^{*} P<0.05$.

Published by Bioscientifica Ltd. 


\section{Activation of ERs by $E_{2}$ analogs}

Compounds NDC-1022, NDC-1308, and NDC-1352 were assayed for transcriptional activity from both ER subtypes, and compared to $\mathrm{E}_{2}$ for reference. Reporter gene transfection assays were conducted in MDA-MB-231 cells using expression plasmids for either full-length ER- $\alpha$ or ER- $\beta$ and an estrogen-responsive luciferase reporter gene system.

Overall, the $\mathrm{E}_{2}$ analogs were more potent agonists of ER- $\beta$ than ER- $\alpha$ (refer to $\beta: \alpha$ functional selectivity in Table 2), but less potent ER activators compared with $\mathrm{E}_{2}$. Functional selectivity was dose-dependent for NDC-1022 and NDC- 1308 as both favored ER- $\beta$ over ER- $\alpha$ at 10 and $100 \mathrm{nM}$. The selectivity was not observed at, or above, $1 \mu \mathrm{M}$ of ligand (Table 2). Treatment of cells with NDC1352 caused 15- to 20 -fold more transcription from the reporter gene for ER- $\beta$ than ER- $\alpha$, even up to the highest concentration of ligand tested $(10 \mu \mathrm{M}$, data not shown), which is consistent with the results from the binding affinity assay.

In a separate follow-up study, the addition of an ER antagonist, ICI $182780(100 \mathrm{nM})$, to the culture media of the cells for the luciferase assay effectively competed away the transcriptional activity of the reporter gene by NDC1022 and NDC-1308 at all concentrations, for both ER- $\alpha$ and ER- $\beta$ (Supplementary Figure 2, see section on supplementary data given at the end of this article). This demonstrates that the $\mathrm{E}_{2}$ analogs are indeed functioning through the ERs.

\section{$E_{2}$ analog-dependent intracellular signaling}

As the gene activity measured by the luciferase functional assays are associated with only one estrogen response element (ERE) and nuclear receptors influence many genes and pathways from various EREs, the global transcriptional effect of the $E_{2}$ analogs was assessed by DNA microarray. Gene expression profiles were determined by microarray in three different human tumor cell lines, which vary in their endogenous amounts of ER- $\alpha$ and ER- $\beta$. A-549 is an ER- $\alpha$ negative, ER- $\beta$ positive human lung adenocarcinoma cell line (Dougherty et al. 2006). Panc-1 is an ER- $\alpha$ positive, ER- $\beta$ positive pancreatic tumor cell line (Mariani 2005). SK-OV-3 is an ER- $\alpha$ positive, ER- $\beta$ positive ovarian tumor cell line; however, there is a 32-bp deletion in ER- $\alpha$ rendering it nonfunctional (Lau et al. 1999). Cells were treated with varying amounts of each $E_{2}$ analog at concentrations ranging from 10 to $100 \mu \mathrm{M}$ in order to ensure complete dimer formation (Fig. 3) and full activation of the ERs (Table 2).
Table 1 summarizes the microarray dataset for differentially expressed genes found in key signaling pathways. Each gene listed in Table 1 was selected due to its common change in expression across all three tumor cell lines following treatment with each compound. The values in the table represent the mean expression $(\log 2)$ across all three cell lines. For NDC-1022 and NDC-1308, all three cell lines showed on average a i) 2- to 75-fold upregulation of genes in signaling pathways related to OPC differentiation, ii) one- to fivefold downregulation of genes for signaling pathways related to chromosome replication, and iii) 1- to 25 -fold upregulation of genes in signaling pathways controlling cell death. For both analogs, the response of the cells at the transcriptional level was dose-dependent, yet the potency of NDC-1308 was significantly greater than NDC-1022. This is best demonstrated by comparing the magnitude of gene expression changes measured at $10 \mu \mathrm{M}$ for NDC-1308 to $100 \mu \mathrm{M}$ for NDC-1022 (Table 1). By contrast, genes within these signaling pathways were relatively unaffected by even the highest concentration of NDC-1352 $(100 \mu \mathrm{M})$. Instead, with NDC-1352, chemokine genes possibly related to the immune system pathways or the pro-inflammatory pathways were upregulated (3- to 200-fold). As expected, housekeeping genes were not significantly up-regulated or uniformly downregulated by the $\mathrm{E}_{2}$ analogs.

As the changes in gene expression lead to distinct signaling pathways for each $\mathrm{E}_{2}$ analog, we reasoned that the pathway information derived from the tumor cell lines could be used to further distinguish the similar $\mathrm{E}_{2}$ analogs from each other in cell-based assays for viability (tumor cell death) and differentiation (neuronal precursor assays).

\section{$E_{2}$ analog-mediated tumor cell death}

The gene expression profiles (Table 1) predict that NDC1308 would be the most potent of the $\mathrm{E}_{2}$ analogs for inducing cell death. To test this, ten different human tumor cell lines obtained from six different tissue types were treated separately, with each of the three $E_{2}$ analogs compared with tamoxifen and $\mathrm{E}_{2}$ as a reference (Table 3). On average, NDC-1308 ( $\left.\mathrm{EC}_{50} 18.0 \pm 2.2\right)$ was the most potent of the $\mathrm{E}_{2}$ analogs followed by NDC-1022 (EC 50 $57.1 \pm 5.5)$ and NDC-1352 (EC 50 117.1 \pm 11.5 ). Treating cancer cells with NDC-1308 showed a dose-dependent ability to kill tumor cell lines with an $\mathrm{EC}_{50}$ ranging from 7 to $31 \mu \mathrm{M}$, which is similar to the potency of tamoxifen and about twofold more potent than $\mathrm{E}_{2}(18-52 \mu \mathrm{M})$.

Published by Bioscientifica Ltd. 

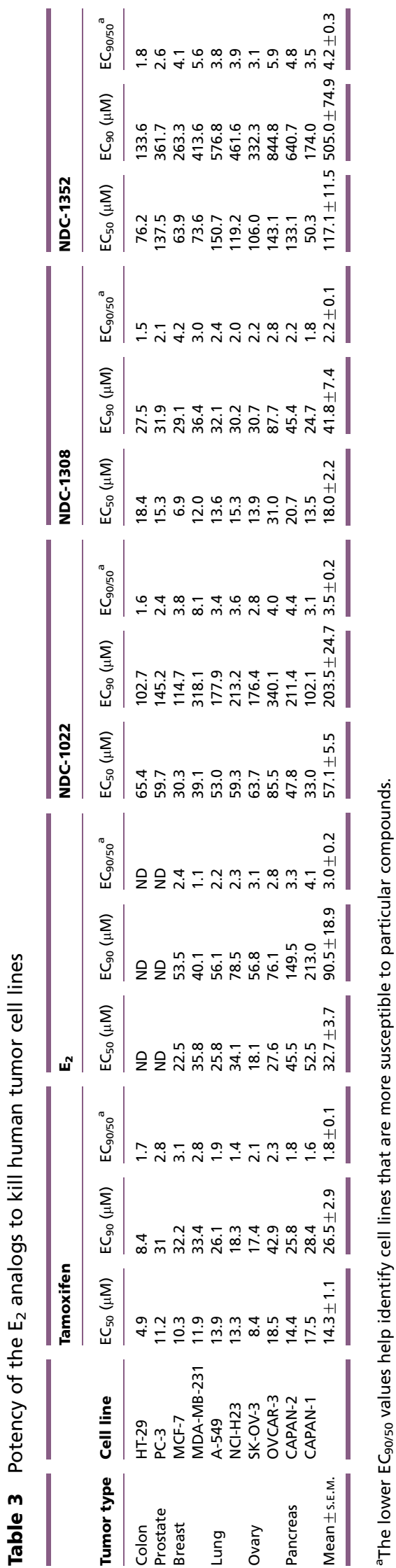

http://www.jme.endocrinology-journals.org DOI: 10.1530/JME-12-0083
C 2013 Society for Endocrinology Printed in Great Britain
NDC-1022 also possessed a dose-dependent cytotoxic activity with an $\mathrm{EC}_{50}$ ranging from 33 to $85 \mu \mathrm{M}$, but as predicted from the microarray data (Table 3 ), was about threefold less potent than NDC-1308. Consistent with the microarray data, the potency of NDC-1352 $\left(\mathrm{EC}_{50}\right.$ $50-150 \mu \mathrm{M})$ was about twofold less than NDC-1022, although the chemical structures are very similar (Fig. 1). The $\mathrm{EC}_{90}$ value was on average two- to tenfold lower for NDC-1308 compared with either $E_{2}$ or the other $E_{2}$ analogs, confirming that the structural changes made in the $\mathrm{E}_{2}$ core affect cell viability.

To test whether the $\mathrm{E}_{2}$ analogs directly induce cell death via the ERs, we used NDC-1352 as a competitive inhibitor for blocking the tumor cell death mediated by NDC-1308. We chose NDC-1352 because it binds almost exclusively to ER- $\beta$ (Table 2), but is five- to tenfold less potent than NDC-1308 in the tumor cell viability assays (Table 3 ). To simplify the potential intracellular interactions of having both ERs present, we used the A549 tumor cell line as it endogenously expresses only a functional ER- $\beta$. We found that addition of $5 \mu \mathrm{M}$ NDC-1352 significantly raised the $\mathrm{IC}_{50}$ (1.4-fold) and $\mathrm{IC}_{90}$ (1.9-fold) of NDC-1308. This means that tumor cell death induced by NDC-1308 is mediated through ER- $\beta$.

\section{$E_{2}$ analog-mediated differentiation of neuronal precursor cells}

The gene expression data (Table 1) show that NDC-1022 and NDC-1308 upregulate genes in signaling pathways involved in myelin production and the differentiation of OPCs. To directly test for this activity, mouse OPCs were treated for $96 \mathrm{~h}$ with $10 \mu \mathrm{M}$ of either NDC-1022, NDC-1308, or NDC-1352 and the extent of oligodendrocyte maturation measured by the level of the PLP-EGFP reporter signal (Fig. 4). Proteolipid protein (PLP) was used as a biomarker, because it is known to be expressed in mature oligodendrocytes and is a component of the myelin sheath. As shown in Fig. 4A, NDC-1308 was the most potent $\mathrm{E}_{2}$ analog having threefold more activity to differentiate OPCs compared with DMSO and 1.5- to 2.0-fold more activity than the positive controls, CNTF (Stankoff et al. 2002) and MEKi (Younes-Rapozo et al. 2009) respectively. The number of pyknotic nuclei for the $\mathrm{E}_{2}$ analog-treated cells ( $\sim 20 \%$ of total) was the same as the control DMSO- and CNTF-treated cells, indicating that the OPCs were not adversely affected by the drug treatment. As predicted from the microarray

Published by Bioscientifica Ltd 
A
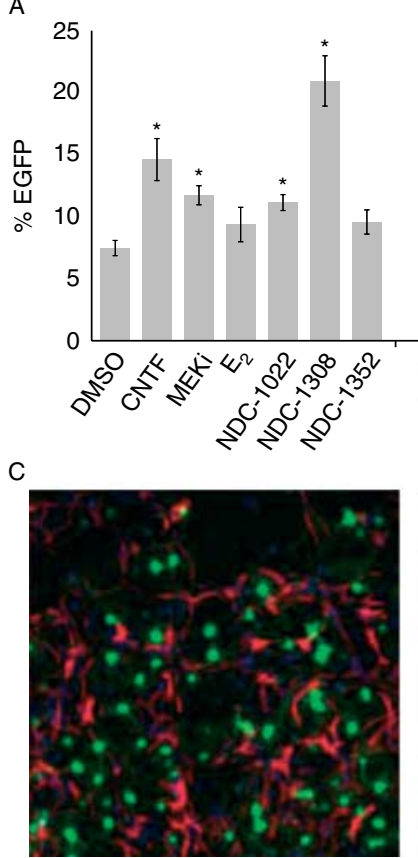

B

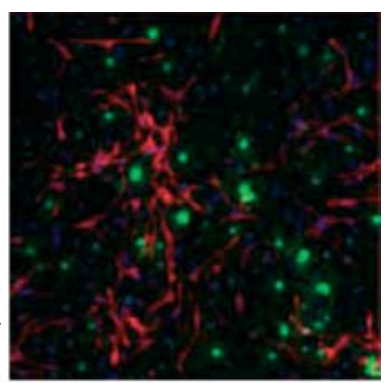

D

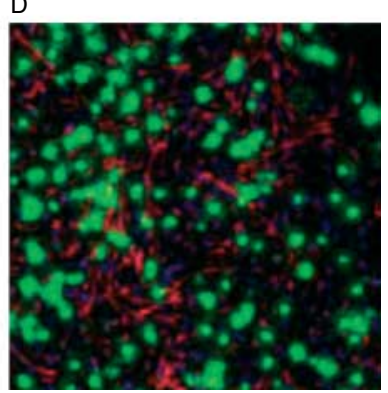

Figure 4

Differentiation of mouse primary OPCs with the $E_{2}$ analogs. OPCs isolated from PLP-EGFP transgenic mice were treated with $E_{2}$, the $E_{2}$ analogs NDC-1022, NDC-1308 and NDC-1352 along with the positive controls CNTF and MEKi. After treatment, the cells were fixed and assayed for luminescence using the Cellomics Arrayscan VTI. Cells expressing EGFP (mature oligodendrocytes) were measured with a neuronal profiling algorithm. (A) Percent EGFP expressing cells ( $y$-axis) after treatment with $E_{2}$ and the $E_{2}$ analogs are compared with negative (DMSO) and positive (CNTF, MEKi) controls. Mean values are plotted with s.D., $n=5$. $P<0.001$ to DMSO is denoted by ' ${ }^{\prime \prime}$. Representative images after treatment with DMSO (B), CNTF (C), and NDC-1308 (D). Visible are mature oligodendrocytes (green cells) and astrocytes (red cells) as well as Hoechst stained nuclei from undifferentiated OPCs (blue).

data, NDC-1352 did not cause significant OPC differentiation at $10 \mu \mathrm{M}$.

\section{Discussion}

Previous reports have described a number of diverse ER ligands without adequately assigning a biological function to different substituents present in the chemical structures (Frasor et al. 2004, Paulmurugan et al. 2011). Towards this end, we integrated gene expression data derived from human tumor cell lines along with receptor binding and cell-based functional assays to ascertain the effect that a change in ER ligand structure imparts on ER function. The three $\mathrm{E}_{2}$ analogs studied here were designed with different substituents added or removed from the $\mathrm{E}_{2}$ core. While all three analogs are ER- $\beta$ agonists, the structural

modifications present in each compound led to unique ER dimerization, different subtype selectivity, and receptor-binding affinities, along with differential effects on gene expression, cell growth, and cell differentiation.

Structure-function relationships with modifications at the C-6 position (B-ring) of the $\mathrm{E}_{2}$ core have not previously been reported. However, our ER modeling data (Fig. 2) suggested that an alkoxyalkyl group addition containing at least four carbons at the C- 6 position would fold over the B-ring of the $\mathrm{E}_{2}$ core. This could still allow the analogs to bind in the $\mathrm{E}_{2}$ orientation, but perhaps bind more compactly in the LBD of the receptor compared with $\mathrm{E}_{2}$. This provided the rationale to synthesize NDC-1308 with a six carbon alkoxyalkyl group at the C-6 position of $\mathrm{E}_{2}$ (Fig. 1, B-ring). As a comparator, NDC-1022 was constructed with a single carbon alkoxyalkyl group added to the $\mathrm{E}_{2}$ core. An additional modification was made at the C-18 (Fig. 1, D-ring) of NDC-1022 by changing the methyl group to a hydrogen atom. The resulting ligand, NDC-1352, is predicted to be primarily oriented in the LBD by virtue of the C-3 and C-17 alcohol groups in the $\mathrm{E}_{2}$ core.

While we originally viewed some of the structural differences in the three $\mathrm{E}_{2}$ analogs to be relatively innocuous compared with $\mathrm{E}_{2}$ and also with each other, it was surprising that each compound had vastly different binding affinity and ER subtype selectivity. NDC-1308 lacked a preferential affinity for either ER- $\alpha$ or ER- $\beta$, while NDC-1022 preferentially bound ER- $\beta$ (greater than fivefold). Remarkably, NDC-1352 bound almost exclusively to ER- $\beta$ ( $>100$-fold). For NDC-1308, the impact of the longer alkoxyalkyl side chain (six carbons) fitting more compactly in the LBD may explain the loss of ER- $\beta$ selectivity for this $\mathrm{E}_{2}$ ligand compared with the other two $\mathrm{E}_{2}$ analogs. The striking gain in ER- $\beta$ selectivity for NDC-1352 and the different gene expression patterns compared with NDC-1022 are solely attributed to the hydrogen substitution for the methyl at C-18 of the D-ring. The competitive binding assays showed that $\mathrm{E}_{2}$ had at least tenfold better binding to ER- $\beta$ and 35 -fold better binding to ER- $\alpha$ than the best $\mathrm{E}_{2}$ analog, probably due to the overall bulkiness of the alkoxyalkyl side chains added to the C- 6 position of each $\mathrm{E}_{2}$ analog.

Moreover, a plausible explanation for why NDC-1308 is more potent and less selective than NDC-1022 is because the longer side chain of NDC-1308 makes additional van der Waals interactions to stabilize it within the ligand-binding cleft of both receptors. The enhanced ER- $\beta$ selectivity of NDC-1022 may be due to the C- 6 side chain making van der Waals contacts with residues that

Published by Bioscientifica Ltd. 
are different between ER- $\alpha$ (Leu-384) and ER- $\beta$ (Met-291). Likewise, the remarkable ER- $\beta$ selectivity of NDC-1352 may be explained by the loss of the C- 18 methyl from the core structure and the interaction it normally makes with these same residues.

ERs bind ligand and dimerize to become part of an active transcription complex. We evaluated the potential of NDC-1022 and NDC-1308 to form ER- $\alpha$ and ER- $\beta$ homo- and heterodimers in vitro as a predictor of their ability to activate and regulate transcription in cell lines. Compounds NDC-1022 and NDC-1308 act similar to other estrogens by causing the formation of ER homo- and heterodimers (Deroo \& Korach 2006). The results of the dimer formation assays showed NDC-1308 to be more promiscuous than NDC-1022 for ERs, consistent with the receptor binding data. That the $\mathrm{E}_{2}$ analogs could specifically activate transcription via ERs was confirmed by functional assays showing that each functions as ER agonists, with no detectable cross-reactivity for the ARs, PRs, and GRs.

Based on their different ER subtype selectivity and knowing that ER activation is not an 'on-off' switch, we anticipated that the $E_{2}$ analogs would elicit different cellular responses. We used microarray data from human tumor cell lines to distinguish the structure of each ligand for key intracellular signaling pathways and ultimately to predict biological responses. Choosing tumor cell lines derived from diverse tissues (lung, pancreas, and ovary) ensured that common signaling pathways would be detected independent of genetic background or levels of ER expression. This strategy also filters away significant gene expression changes that are due to cell line-specific coactivators and corepressors. In addition, the human tumor cell lines were treated with micromolar concentrations of each $\mathrm{E}_{2}$ analog to ensure full dimerization (Fig. 3) and activation (Table 2) of the ERs within the $24 \mathrm{~h}$ incubation period. We were able to identify common signaling pathways in all three human tumor cell lines for each $\mathrm{E}_{2}$ analog.

Identifying the dramatic regulation of key genes within several specific signaling pathways helped us predict the biological response for each $\mathrm{E}_{2}$ analogs. For example, the dramatic upregulation of $M B P, O L I G 2$, and $M O G$ at the lowest dose of NDC-1308 $(10 \mu \mathrm{M})$ predicted an activity for differentiation of OPCs. This was confirmed in vitro using a mouse OPC differentiation assay (Fig. 4) where NDC-1308 had the most potent activity $\left(\mathrm{EC}_{50}\right.$ $1.0 \mu \mathrm{M}$, data not shown). Conversely, at higher concentrations both NDC-1308 $(50 \mu \mathrm{M})$ and NDC-1022 $(100 \mu \mathrm{M})$ caused dramatic downregulation of MCM4, MCM10,
GTSE1, SPC25, and other genes essential for chromosome replication. Moreover, NDC-1308 and NDC-1022 cause a substantial upregulation of genes for cell death including GDF15, GZMK, and GADD45A. This predicted cytotoxic activity at higher concentrations of the $\mathrm{E}_{2}$ analogs, which was confirmed in the cell-based viability assay for both NDC-1308 and NDC-1022 (Table 3). That NDC-1352 is less cytotoxic and does not cause OPC differentiation is consistent with the gene expression data, and points out the dramatic effect that a hydrogen substitution for a methyl group can make at C-18 of the core $\mathrm{E}_{2}$. NDC-1352 does elicit a dramatic upregulation of chemokine, metallopeptidases, and a complement component suggesting a potential role in stimulating inflammation. Notably, this specific transcriptional upregulation is absent in NDC-1308 and NDC-1022.

As described above, the altered transcriptional activities of these $\mathrm{E}_{2}$ analogs could be attributed to conformational changes in the ER resulting from adding the different C-6 alkoxyalkyl side chains. Likewise, removing the C-18 methyl group of the $\mathrm{E}_{2}$ core affected ER activation. Except for a hydrogen atom substituted in place of a methyl at C-18, NDC-1352 is structurally identical to NDC-1022. The modeling data suggest that the absence of the C-18 methyl group of NDC-1352 allows for a better fit of the C- 6 side chain in ER- $\beta$ than in ER- $\alpha$. This could explain why remarkably different gene expression differences were obtained in key signaling pathways for NDC-1352 compared with NDC-1022. Taken together, the comparison of gene expression and functional data for NDC-1352 and NDC-1022 demonstrates how a critical alteration in the core $\mathrm{E}_{2}$ structure can dramatically alter the cellular response.

Our data confirm and extend the notion that the inherent structure of specific ER ligands has a major impact on gene expression events that control cell fate. Structural modifications of $E_{2}$ analogs at the C- 6 and C- 18 positions led to dramatic differences in the activation of the ERs that ultimately led to tumor cell death or neuronal cell differentiation. The use of ER competitors in transcriptional assays and the cell viability assay is consistent with the activity of the $\mathrm{E}_{2}$ analogs being directed through the ERs. Furthermore, the activities reported here only require the presence of functional ER- $\beta$ as two (A-549 and SK-OV-3) of the three tumor cell lines used for the microarray study do not make a functional ER- $\alpha$ protein. These studies support the notion that by using this approach for drug discovery, ligands for nuclear receptors may be designed for treating a variety of diseases, such as multiple sclerosis and cancer.

Published by Bioscientifica Ltd. 


\section{Supplementary data}

This is linked to the online version of the paper at http://dx.doi.org/10.1530/ JME-12-0083.

\section{Declaration of interest}

The authors declare that RE B, M B, E S, W X, and P H have nothing to disclose that could be perceived as prejudicing the impartiality of the research reported. J G Y and S H N are shareholders of ENDECE, LLC.

\section{Funding}

This research did not receive any specific grant from any funding agency in the public, commercial, or not-for-profit sector.

\section{Acknowledgements}

The authors thank Brian Bai and Caroline Lego of Renovo Neural for assistance with the OPC cultures and oligodendrocyte maturation assays, Andrea Hubbel of Ricerca Biosciences for assistance with the cytotoxicity assays, and Wan-Ru Chao of SRI International for assistance with the receptor-binding and functional assays. They also thank Mark Verhaar, Erik Keller, and Martin Poelert of Syncom for the synthesis of the compounds used in this study. Finally, they thank Bruce Trapp for critically reviewing the manuscript.

\section{References}

Barkhem T, Carlsson B, Nilsson Y, Enmark E, Gustafsson J \& Nilsson S 1998 Differential response of estrogen receptor $\alpha$ and estrogen receptor $\beta$ to partial estrogen agonists/antagonists. Molecular Pharmacology 54 105-112.

Brzozowski AM, Pike AC, Dauter Z, Hubbard RE, Bonn T, Engstrom O, Ohman L, Greene GL, Gustafsson JA \& Carlquist M 1997 Molecular basis of agonism and antagonism in the oestrogen receptor. Nature $\mathbf{3 8 9}$ 753-758. (doi:10.1038/39645)

Chung AC \& Cooney AJ 2003 The varied roles of nuclear receptors during vertebrate embryonic development. Nuclear Receptor Signaling 1 e007. (doi:10.1621/nrs.01007)

Colasanti T, Maselli A, Conti F, Sanchez M, Alessandri C, Barbati C, Vacirca D, Tinari A, Chiarotti F, Giovannetti A et al. 2011 Autoantibodies to estrogen receptor $\alpha$ interfere with T lymphocyte homeostasis and are associated with disease activity in systemic lupus erythematosus. Arthritis and Rheumatism 64 778-787. (doi:10.1002/art. 33400)

Connor CE, Norris JD, Broadwater G, Willson TM, Gottardis MM Dewhirst MW \& McDonnell DP 2001 Circumventing tamoxifen resistance in breast cancers using antiestrogens that induce unique conformational changes in the estrogen receptor. Cancer Research 61 2917-2922.

Couse JF, Lindzey J, Grandien K, Gustafsson JA \& Korach KS 1997 Tissue distribution and quantitative analysis of estrogen receptor- $\alpha(\operatorname{ER} \alpha)$ and estrogen receptor- $\beta$ (ER $\beta$ ) messenger ribonucleic acid in the wild-type and ER $\alpha$-knockout mouse. Endocrinology 138 4613-4621. (doi:10.1210/ en.138.11.4613)

Danielian PS, White R, Lees JA \& Parker MG 1992 Identification of a conserved region required for hormone dependent transcriptional activation by steroid hormone receptors. EMBO Journal 11 1025-1033.

Deroo BJ \& Korach KS 2006 Estrogen receptors and human disease. Journal of Clinical Investigation 116 561-570. (doi:10.1172/JCI27987)

http://www.jme.endocrinology-journals.org DOI: $10.1530 / J M E-12-0083$
C 2013 Society for Endocrinology Printed in Great Britain
Dougherty SM, Mazhawidza W, Bohn AR, Robinson KA, Mattingly KA, Blankenship KA, Huff MO, McGregor WG \& Klinge CM 2006 Gender difference in the activity but not expression of estrogen receptors $\alpha$ and $\beta$ in human lung adenocarcinoma cells. Endocrine-Related Cancer 13 113-134. (doi:10.1677/erc.1.01118)

Frasor J, Stossi F, Danes JM, Komm B, Lyttle CR \& Katzenellenbogen BS 2004 Selective estrogen receptor modulators: discrimination of agonistic versus antagonistic activities by gene expression profiling in breast cancer cells. Cancer Research 64 1522-1533. (doi:10.1158/00085472.CAN-03-3326)

Katzenellenbogen JA 2011 The 2010 Philip S. Portoghese Medicinal Chemistry Lectureship: addressing the "core issue" in the design of estrogen receptor ligands. Journal of Medicinal Chemistry 54 5271-5282. (doi:10.1021/jm200801h)

Kimbrel EA \& McDonnell DP 2003 Function and mode of action of nuclear receptors: estrogen, progesterone, and vitamin D. Pure and Applied Chemistry 75 1671-1683. (doi:10.1351/pac200375111671)

Lau KM, Mok SC \& Ho SM 1999 Expression of human estrogen receptor- $\alpha$ and $-\beta$, progesterone receptor, and androgen receptor mRNA in normal and malignant ovarian epithelial cells. PNAS 96 5722-5727. (doi:10.1073/pnas.96.10.5722)

Mallon BS, Shick HE, Kidd GJ \& Macklin WB 2002 Proteolipid promoter activity distinguishes two populations of NG2-positive cells throughout neonatal cortical development. Journal of Neuroscience 22 876-885.

Mariani SM 2005 Phytoestrogens and antioxidants - bits of experimental evidence. Medscape General Medicine 725.

Moore JT, Collins JL \& Pearce KH 2006 The nuclear receptor superfamily and drug discovery. ChemMedChem 1 504-523. (doi:10.1002/cmdc. 200600006)

Paruthiyil S, Cvoro A, Zhao X, Wu Z, Sui Y, Staub RE, Baggett S, Herber CB, Griffin C, Tagliaferri M et al. 2009 Drug and cell type-specific regulation of genes with different classes of estrogen receptor $\beta$-selective agonists. PLoS ONE 4 e6271. (doi:10.1371/journal.pone.0006271)

Paulmurugan R, Tamrazi A, Massoud TF, Katzenellenbogen JA \& Gambhir SS 2011 In vitro and in vivo molecular imaging of estrogen receptor $\alpha$ and $\beta$ homo- and heterodimerization: exploration of new modes of receptor regulation. Molecular Endocrinology 25 2029-2040. (doi:10.1210/ me.2011-1145)

Pedraza CE, Monk R, Lei J, Hao Q \& Macklin WB 2008 Production, characterization, and efficient transfection of highly pure oligodendrocyte precursor cultures from mouse embryonic neural progenitors. Glia 56 1339-1352. (doi:10.1002/glia.20702)

Pfleger KD \& Eidne KA 2006 Illuminating insights into protein-protein interactions using bioluminescence resonance energy transfer (BRET). Nature Methods 3 165-174. (doi:10.1038/nmeth841)

Pike AC, Brzozowski AM, Walton J, Hubbard RE, Thorsell AG, Li YL, Gustafsson JA \& Carlquist M 2001 Structural insights into the mode of action of a pure antiestrogen. Structure 9 145-153. (doi:10.1016/S09692126(01)00568-8)

Powell E \& Xu W 2008 Intermolecular interactions identify ligand-selective activity of estrogen receptor $\alpha / \beta$ dimers. PNAS $10519012-19017$. (doi:10.1073/pnas.0807274105)

Ribas V, Drew BG, Le JA, Soleymani T, Daraei P, Sitz D, Mohammad L, Henstridge DC, Febbraio MA, Hewitt SC et al. 2011 Myeloid-specific estrogen receptor $\alpha$ deficiency impairs metabolic homeostasis and accelerates atherosclerotic lesion development. PNAS $\mathbf{1 0 8}$ 16457-16462. (doi:10.1073/pnas.1104533108)

Ruff M, Gangloff M, Wurtz JM \& Moras D 2000 Estrogen receptor transcription and transactivation: structure-function relationship in DNA- and ligand-binding domains of estrogen receptors. Breast Cancer Research 2 353-359. (doi:10.1186/bcr80)

Shiau AK, Barstad D, Loria PM, Cheng L, Kushner PJ, Agard DA \& Greene GL 1998 The structural basis of estrogen receptor/coactivator recognition and the antagonism of this interaction by tamoxifen. Cell 95 927-937. (doi:10.1016/S0092-8674(00)81717-1) 
Stankoff B, Aigrot MS, Noel F, Wattilliaux A, Zalc B \& Lubetzki C 2002 Ciliary neurotrophic factor (CNTF) enhances myelin formation: a novel role for CNTF and CNTF-related molecules. Journal of Neuroscience 22 9221-9227.

Strauss L, Kallio J, Desai N, Pakarinen P, Miettinen T, Gylling H, Albrecht M, Makela S, Mayerhofer A \& Poutanen M 2009 Increased exposure to estrogens disturbs maturation, steroidogenesis, and cholesterol homeostasis via estrogen receptor $\alpha$ in adult mouse Leydig cells. Endocrinology 150 2865-2872. (doi:10.1210/en.2008-1311)
Via M 2010 Nuclear Receptor: The Pipeline Outlook Report - Overview. In Insight Pharma Reports, pp 1-111, Cambridge Healthtech Institute, Needham, MA.

Younes-Rapozo V, Felgueiras LO, Viana NL, Fierro IM, Barja-Fidalgo C, Manhaes AC \& Barradas PC 2009 A role for the MAPK/ERK pathway in oligodendroglial differentiation in vitro: stage specific effects on cell branching. International Journal of Developmental Neuroscience $\mathbf{2 7}$ 757-768. (doi:10.1016/j.ijdevneu.2009.08.014)

Received in final form 14 September 2012

Accepted 6 November 2012

Accepted Preprint published online 6 November 2012
() 2013 Society for Endocrinology Printed in Great Britain
Published by Bioscientifica Ltd. 